\title{
Goebbels's Iowan: \\ Frederick W. Kaltenbach and \\ Nazi Short-Wave Radio Broadcasts \\ to America, 1939-1945
}

\section{Clayton D. LAURIE}

ON AN EARLY JUNE EVENING in 1940 the residents of eastern Iowa heard a voice on their radios that sounded "midwestern," a voice indistinguishable from those they heard every day at the local drugstore, tavern, or post office. Coming across "as clear as a bell" from Nazi Germany, the voice was speaking directly to them, to "friends in Dubuque and the midwest." In a program called "Letters to Iowa," the broadcaster often addressed "Harry," a childhood friend in Waverly, Iowa. "Dear Harry," this weekly program opened, "what a picture it is to see Hermann Goering's war birds soaring overhead! Boy are they fast!" Changing to a more serious tone, the voice would warn in flawless English, "Don't let the British drag America into this thing, Harry," meaning the widening war in Europe. "Don't pull Britain's chestnuts out of the fire again."

Many Iowans were surprised to learn that the broadcaster they could hear several times each week on the short-wave radio was one of their own, an Iowa-born American named

1. Memo, Flinn to Mumford, 15 October 1942, FBI File 65-6568-41, p. 2. See also Harwood L. Childs and John B. Whitton, eds., Propaganda by Shortwave (Princeton, NJ, 1942), 65; Z. A. B. Zeman, Nazi Propaganda (London, 1973), $57-60$.

THE ANNALS OF IOWA 53 (Summer 1994). CThe State Historical Society of Iowa, 1994. 
Frederick W. Kaltenbach who worked for the U.S.A. Zone of Paul Joseph Goebbels's Ministry of Propaganda. Kaltenbach was one of eight "radio traitors" and one of 141 other Americans accused of having committed treason by aiding the Axis during World War II. ${ }^{2}$

During the immediate postwar years these "renegades" were thought to be mentally unbalanced, calloused and egomaniacal malcontents, racists, cowards, or misfits, "partial failures or frustrates," unable to discriminate between reality and hallucination. Foreign correspondent William L. Shirer, who knew many of the renegades before the war, described most of them in a 1943 article as being no different than other "human derelicts" who were drawn to Nazism during the interwar years "as a flame attracts a moth." All were believed to be rootless individuals incapable of integrating into normal society. ${ }^{3}$

Some renegades were indeed mentally unstable or were driven by anti-Semitism, greed, unrequited love, or opportunism; but others, including Frederick Kaltenbach, appear to have been motivated by ideological zeal and political conviction. Kaltenbach sincerely believed that fascism was a new, youthful, and vigorous form of government representing the wave of the future. Fascism, he was convinced, was capable of saving Germany, the United States, and all of western civilization from a worldwide Bolshevik conspiracy. To Kaltenbach, and to many disillusioned Europeans and Americans during the 1930s, fascism promised to end the social, economic, and political lethargy that characterized the seemingly feeble and plodding liberal democracies. To those who had suffered through two decades

2. For the 141 Americans accused of treason, see file 13, box 346, record group 260, Records of the Office of the Military Government, United States, National Archives. Records on several of the radio traitors may be found in record group 319, Records of the Army Staff, National Archives. FBI files on Frederick Kaltenbach were obtained by the author through a Freedom of Information Act request and are open to the public at FBI Headquarters in Washington, D.C. The most recent published account of the radio traitors is John Carver Edwards, Berlin Calling: American Broadcasters in Service to the Third Reich (Westport, CT, 1991), who discusses Kaltenbach on pp. 8-15.

3. William L. Shirer, "The American Radio Traitors," Harper's Magazine, October 1943, 397. See also Nathaniel Weyl, Treason: The Story of Disloyalty and Betrayal in American History (Washington, DC, 1950), 361-63. 
of war, revolution, economic depression, and civil unrest, Hitler and Mussolini offered visions and ideas that some believed could lead Europe back to the security, stability, and prosperity not known since before 1914 . Kaltenbach saw himself as a messenger whose mission was to warn Americans of the dangers presented by Bolshevism. He also saw himself as an oracle sent to clarify the Nazi philosophy for the American public while simultaneously combating Hitler's critics. Unlike many of the renegades, however, Kaltenbach was an educated man from humble circumstances who gave few indications during his youth that he would one day become a traitor in the service of the Third Reich. ${ }^{4}$

FREDERICK W. KALTENBACH was born in Dubuque, Iowa, on March 29, 1895, the eldest of four sons and one daughter born to John Kaltenbach, a Presbyterian butcher who had emigrated to the United States from Germany four years before. Within a year of Frederick's birth, the Kaltenbachs, who were described by a neighbor as good, honest, and humble people of the lower class, settled in Waterloo, Iowa. Frederick seems to have had a normal childhood, attending the Waterloo Public Schools prior to his graduation from East High School in 1914. He was "a studious, introspective youth" and a champion debater, although one neighbor later claimed that Frederick was an "uncouth and rather sordid person" who was "always antag-

4. For general discussions of treason, see Weyl, Treason; Rebecca West, pseud., The Meaning of Treason (New York, 1947); Margaret Boveri, Treason in the Twentieth Century, trans. Jonathan Steinberg (London, 1961); William Schofield, Treason Trial (New York, 1964); and Kurt Singer, Spies and Traitors of World War II (New York, 1945). For the attraction of fascism in the interwar period, see Lawrence Dennis, The Coming American Fascism (New York, 1936); Leland V. Bell, "The Failure of Nazism in America: The German American Bund, 1936-1941," Political Science Quarterly 85 (1970), 589-99; idem, In Hitler's Shadow: The Anatomy of American Nazism (Port Washington, NY, 1973); Sander A. Diamond, The Nazi Movement in the United States, 1924-1941 (Ithaca, NY, 1974); Seymour Martin Lipset and Earl Raab, The Politics of Unreason: RightWing Extremism in America, 1790-1970 (New York, 1970); Donald M. McKale, The Swastika Outside Germany (Kent, OH, 1977); and Ronald W. Johnson, "The German American Bund and Nazi Germany, 1936-1941," Studies in History and Society 6 (1975), 31-45. 
onistic and 'Communistic' [sic] he could get along with no one."

As a high school graduation present from their father, Frederick and his younger brother Gustav went on a bicycle tour of Germany. The youths were in Germany when the Great War began in August 1914 and were arrested by the authorities on suspicions of espionage. They were detained until December while the family, with the aid of an Iowa congressman, sought their release. In spite of this ordeal, and even though he was born and raised in America, Frederick loved Germany. He wrote that during this first visit "I was swept by a powerful emotion and something inside me said I am going home." ${ }^{16}$

On his return to the states, Frederick began a lengthy term of academic study by entering Grinnell College in Grinnell, Iowa. During his three years as an undergraduate he demonstrated talents as both an orator and a debater. He was known to his classmates as "the Kaiser" and, according to later reports, did not mix well with the rest of the student body. Kaltenbach spent much of his free time earning the considerable sum needed to finance his education by working as a janitor. In addition, as was so common in the prewar years when military preparedness was stressed on campuses, Kaltenbach drilled with one of the three military units formed at Grinnell.

Following the close of his junior year Frederick enlisted in the U.S. Army and was inducted into the service at Waterloo

5. Memo, Flinn to Mumford, 2. See also "Kaltenbach - Chief of Berlin Radio Propagandists," p. 4, FBI File 65-6568-41 (hereafter cited as "Kaltenbach Chief of Berlin Radio Propagandists"); A. C. C. Clifton, "Voice from Berlin Once an Iowan," Des Moines Register, 24 December 1939, in FBI File 65-6568-5; Memo, J. Edgar Hoover to Special Agent in Charge, Des Moines, Iowa, 26 February 1940, FBI File 65-6568-6; Charles J. Rolo, "Germany Calling!" Current History 52 (22 October 1940), 28; and idem, Radio Goes to War: The Fourth Front (New York, 1942), 97.

6. Kaltenbach, as quoted in Edwards, Berlin Calling, 8. See also "KaltenbachChief of Berlin Radio Propagandists," 5. Later FBI reports claimed that Kaltenbach attempted to join the German army while on this bicycle tour. See Summary of Facts of the Case, Kaltenbach Treason Indictment, 17 July 1945, FBI File 65-6568-201 (hereafter cited as Summary of Facts).

7. Clifton, "Voice from Berlin Once an Iowan"; Edwards, Berlin Calling, 8. See also Shirer, "American Radio Traitors," 402. 
on June 10,1918. Because of his level of education and his prior student military training, Frederick was commissioned as a second lieutenant in the U.S. Army Coastal Artillery. Don Beams of Ames, Iowa, one of Kaltenbach's bunkmates while they were stationed at Fort Tilden, New York, told the Iowa Legionnaire Magazine in 1942 that "Kaltenbach was a heel then, as well as now." Due to his late enlistment and particular branch of the army, Kaltenbach never saw service overseas, as the armistice ending the war was signed soon after his commissioning. He left the service in April 1919 along with the tens of thousands of other soldiers honorably discharged in the rush to demobilize after the war. Soon after he returned home he joined the Waterloo post of the American Legion and the field artillery reserve, maintaining memberships in both organizations until $1936 .{ }^{8}$

In the fall of 1919 Kaltenbach resumed his education at Iowa State Teachers College (now the University of Northern Iowa) in Cedar Falls, where he earned his B.A. in 1920. Classmates remembered "Fritz" Kaltenbach as a dogmatic and domineering personality who was an average student. After graduation, Kaltenbach worked for seven years as a farm appraiser. Then he turned to teaching. He first obtained a position as a high school American history instructor in Manchester, Iowa. Then in 1931 he obtained a better job teaching business law, economics, history, and debate at Dubuque Senior High School. Still single at age 36 , Kaltenbach lived a simple life: he resided at the YMCA, took French language courses at night, and earned an M.A. in history from the University of Chicago through courses completed during his summer vacations. In most respects he appeared to be a model citizen who worked hard, kept out of trouble, voted in local and national elections, and served the community, most notably as the first president of the Waterloo YMCA, which later struck his name from its records. ${ }^{9}$

8. Memo, Flinn to Mumford, 1; Iowa Legionnaire Magazine, 16 October 1942, in Bureau Letter to Baltimore, 30 November 1942, FBI File 65-6568, no. 15628; "Kaltenbach - Chief of Berlin Radio Propagandists," 5; and Summary of Facts. See also Edwards, Berlin Calling, 8; and Rolo, "Germany Calling!" 28.

9. Summary of Facts; Edwards, Berlin Calling, 8; Shirer, "American Radio Traitors," 402; and Memo, Flinn to Mumford, 2. On Kaltenbach and the Waterloo YMCA, see Waterloo Daily Courier, 26 January 1946, in FBI File 65-6568-85. 
IN JUNE 1933 Kaltenbach received a scholarship from the University of Berlin to work on a Ph.D., so he was granted a twoyear leave of absence from teaching to pursue graduate study in Germany. Germany had changed considerably since his 1914 visit, having endured the First World War, revolution, hyperinflation, political instability, and the worst effects of the Great Depression. The American was shocked by the conditions he observed, but encouraged by the promise he saw in the new Nazi regime. "There was unemployment everywhere," he wrote, "and in the industrial areas every one of them [workers] were Communists, while Jews were living in luxury. Then Hitler came and gave the German people a new lease on life." ${ }^{10}$

Following two years of study, during which time he observed firsthand the changes made by the Nazis, Kaltenbach returned to Dubuque. Immediately he set off a storm of controversy. In the fall of 1935 he formed a high school student group named the Militant Order of Spartan Knights. While the organization was innocently named after the school's mascot, it bore the unmistakable characteristics of the Nazi Hitler Youth movement. Under Kaltenbach's leadership the coed group held secret initiation rituals, dressed in brown military-style uniforms, and allegedly carried menacing walking sticks during their weekend hikes. The group's activities raised the suspicions of the local community. Hoping to allay them, the Americanism Committee of Dubuque's American Legion called Kaltenbach to appear before the group to explain his actions. The meeting did not go well. According to one Legionnaire, "as he [Kaltenbach] stepped from the Legion platform, after lecturing on his doctrine of leadership, a Legionnaire floored him with a blow to the jaw. Other Legionnaires also got in a few licks in registering what they termed an active protest before order was restored." Kaltenbach allegedly threatened the post commander and promised revenge. The school board subsequently disbanded Kaltenbach's youth group and in June 1936 terminated his teaching contract. ${ }^{11}$

10. Kaltenbach, as quoted in Edwards, Berlin Calling, 8-9. See also Summary of Facts.

11. "Kaltenbach - Chief of Berlin Radio Propagandists," 6; Summary of Facts; Edwards, Berlin Calling, 9; and Shirer, "American Radio Traitors," 402. 
Following his dismissal, Kaltenbach returned to Germany to resume his studies. He supported himself as a free-lance writer and translator who on occasion worked for the shortwave radio network of the Nazi Ministry of Propaganda. ${ }^{12}$ During this period Kaltenbach also wrote a monograph titled Self-Determination dealing with the controversial territorial settlements of the 1919 Treaty of Versailles. In that work he condemned the Allied powers and the language tests, ethnological statistics, and election returns used to determine postwar national boundaries and ethnic memberships. To Kaltenbach, "Nationality" was "a state of mind, a subjective psychological feeling that transcends race," and was largely sentimental. It was not something that could be arbitrarily created by diplomacy. "Blood is thicker than water," Kaltenbach wrote, "and those who lightly choose to disregard this do so at their peril." Kaltenbach said that writing Self-Determination convinced him of the justice of the Nazi cause. Already a German ultranationalist, he became an indiscriminate supporter of the Nazis. ${ }^{13}$

As Kaltenbach neared completion of his studies in February 1939, he married Dorothea Peters, a 38-year-old German woman from an old military family. His new wife had contacts within the Nazi Party and was herself employed as a secretary on the staff of one of Luftwaffe Chief Hermann Goering's aviation journals. Within weeks of their marriage, Kaltenbach was placed in contact with those controlling the U.S.A. Zone of the Nazi short-wave radio network and was hired as a broadcaster along with several other Americans living in Germany. ${ }^{14}$ Soon there-

12. Memo, Flinn to Mumford, 2; Clifton, "Voice from Berlin Once an Iowan." A newspaper report later claimed that Kaltenbach had declined a U.S. State Department job at this time paying an annual salary of $\$ 3,600$. FBI records do not mention this.

13. Edwards, Berlin Calling, 9. See also Washington Star, 21 July 1946. Kaltenbach's book is Self-Determination (London, 1938).

14. For the radio traitors, see Shirer, "American Radio Traitors," 397-401; Allan Miche, "Letters to Iowa," Reader's Digest 36 (June 1940), 17-21; J. O. Rennie, "Dr. Goebbels' Awkward Squad," Atlantic 172 (September 1943), 107; David G. Wittels, "Hitler's Short Wave Rumor Factory," Saturday Evening Post 215 (21 November 1942), 12-13; and Samuel Lipman, "German Wartime Broadcasts," Commentary 63 (March 1977), 72-75. 
after the newlyweds went on a honeymoon in the United States with all their expenses paid by the Ministry of Propaganda.

During their trip to America, the Kaltenbachs visited all of Frederick's siblings, stopping first to see his brother Gustav, a clergyman with the First Presbyterian Church in Ironwood, Michigan. The elder Kaltenbach prevailed upon his younger brother to allow him to speak from the pulpit, where he presented a lecture on the Nazi philosophy. Frederick and his wife next went to Ottumwa, Iowa, to visit another brother, Erwin J. "Butch" Kaltenbach, a teacher and basketball coach at Ottumwa High School. Kaltenbach took every opportunity to address local citizens' groups on National Socialism. In early April he spoke to both the Ottumwa Rotary and Kiwanis Clubs and to student groups at the University of Iowa in Iowa City. While his comments were generally received negatively by his audiences, one concerned citizen later claimed that many people, especially the impressionable students at the University of Iowa, "were actually taken in with his suavity and reasoning. ${ }^{15}$

Kaltenbach's last stop was at his hometown of Waterloo, where he visited his dying father, a widower since 1930, and other nearby siblings. Kaltenbach's father, who died on May 20, 1939, while Frederick was en route back to Germany, was an ardent German nationalist until the day he died, even though he had been a naturalized American citizen since 1896; and he was reportedly quite proud of his son's work for the Nazi government. ${ }^{16}$

During his stay in Waterloo, Kaltenbach addressed a May Day Rotarian luncheon at the Russell-Lampson Hotel. In his speech on the virtues of National Socialism, he referred to Germany's 1936 reoccupation of the Rhineland as "moving into her own backyard," and he defended the 1938 Austrian Anschluss and 1939 dismemberment of Czechoslovakia as self-

15. See [name deleted] to J. Edgar Hoover, 3 February 1940, FBI File 65-6568-55; Edwards, Berlin Calling, 9; Rolo, "Germany Calling!" 28; Memo, Flinn to Mumford, 3; "Kaltenbach - Chief of Berlin Radio Propagandists," 4; and Summary of Facts. See also Chicago Sunday Tribune, 3 December 1942; and Washington Post, morning edition, 12 September 1942, both in FBI File 65-6568-A.

16. Summary of Facts; Edwards, Berlin Calling, 9; Shirer, "American Radio Traitors," 398; and Rolo, Radio Goes to War, 97. 
determination in the strictest sense as advocated by Woodrow Wilson. In perhaps one of his more ominous statements, he told the Rotarians that "Germany will take over the Polish Corridor and the Free City of Danzig whenever she wants to." For his lecture Kaltenbach received twenty-five dollars and, according to one source, a round of jeers and catcalls. Many in the group openly denounced him as a Nazi agent. Within days the Kaltenbachs cut short their plans to stay in Iowa all summer and hurriedly returned to Germany, allegedly to aid in the preparations for the Nazi attack on Poland set for September 1, 1939.17

SHORTLY BEFORE THE WAR BEGAN Kaltenbach went on the air as a propagandist. Slowly, over the course of months, he was identified by radio monitors employed by the Foreign Broadcast Intelligence Service of the Federal Communications Commission (FBIS/FCC) in the United States. By Thanksgiving 1939 Kaltenbach had revealed enough about himself in his monitored Monday night broadcasts to be identified as an American from Iowa. He later removed any doubts when he sent a postcard to the Waterloo Daily Courier informing Iowans when they could hear his four weekly broadcasts over Nazi short-wave stations. ${ }^{18}$

Soon after the war began, State Department officials contacted all Americans living in Germany, including Kaltenbach, to encourage them to return home before they were stranded abroad. Kaltenbach ignored this advice and asked instead that his residence visa be extended until February 1940, a request that was granted. When this term expired and Kaltenbach was once more encouraged to return to America, he again declined, stating that he was very busy with his work as a translator and broadcaster and that he wished to remain in Germany for the duration, citing plans to publish a book on the recent Polish campaign. During questioning he reaffirmed his loyalty to the

17. Quotes from Waterloo Daily Courier, 1 May 1939. See also Edwards, Berlin Calling, 9; Rolo, "Germany Calling!" 28; "Kaltenbach - Chief of Berlin Radio Propagandists," 6; and Clifton, "Voice from Berlin Once an Iowan."

18. "Kaltenbach - Chief of Berlin Radio Propagandists," 4; Clifton, "Voice from Berlin Once an Iowan"; and news article of unknown origin titled "Kaltenbach Gives Radio Talks from Berlin to Iowans," in FBI File 65-6568-5. 
United States and claimed no love for Nazism. He did, however, declare the deepest sympathy for the German people. When inquiries were made about his employer and his role as a radio broadcaster, Kaltenbach stated that ever since visiting Germany in 1914 he had done what he could to "further the relations between the land of my father, Germany, and my native land, America. I love them both." He told American officials how proud he was of his Nazi Party affiliations and employment with the Ministry of Propaganda. Taking into account his employment by a foreign government, the State Department refused to grant a new extension of Kaltenbach's visa when it expired in April 1940. ${ }^{19}$

How far Kaltenbach had converted to National Socialism by 1939 is not clear, but he had publicly voiced strong Nazi sympathies in the past, and, like most Nazis, he was an antiSemite with an arrogant disdain for democracy. Yet he continued to claim a dual patriotism and saw his service to the Nazis as being in the best interests of both Germany and the United States. It was evident that Kaltenbach saw no conflict of interest between his work for the Nazis, his German heritage, and his American citizenship. As he had written to a friend in 1937, "We German-Americans with our traditional conservatism cannot stand by and see our American spiritual heritage threatened by Bolsheviks like labor leader [John L.] Lewis and his ilk. We still cling to those ideals of homespun Democracy which Lincoln stood for. The German element helped Lincoln save the union. Maybe we are today called to save America." Kaltenbach also indicated a strong belief that National Socialism represented a bulwark against Communism. He viewed the leaders of the Soviet Union as blood-stained criminals who were seeking to overthrow the West in league with Jews and other anti-Nazi elements. Like many other Europeans, Kaltenbach believed in the slogan "better Hitler than Stalin." Stung by American criticisms of Hitler that he thought were unjust and without merit, Kaltenbach claimed publicly that such rhetoric was motivated by American jealously of Germany's renaissance during the

19. Kaltenbach, quoted in Edwards, Berlin Calling, 8. See also Memo, Flinn to Mumford, 2. 
1930s. "Roosevelt," he explained, "knew he could not tackle the social ills the way the Americans thought he could and should, and the only way was to blame Hitler for his [Roosevelt's] failure and to detract public criticism by focusing attention on an imaginary threat from the other side of the ocean. ${ }^{20}$

American journalist Joseph C. Harsch, writing for the Christian Science Monitor, claimed that Kaltenbach was "the most effective [radio traitor] from the German point of view because he ... is also sincere in his Nazism." Commenting on Kaltenbach's engaging personality and "courage - even when it comes to differences of opinion with his employers," Harsch recalled that Kaltenbach had "preached and argued it [Nazism] with me most of the way from Berlin to Paris on a three-day bus trip." ${ }^{21}$ William Shirer, who also knew Kaltenbach, agreed that the Iowan was "most sincere in his conversion to Nazism. He really believed in it. ... He remained essentially German in outlook and like so many other Germans was early attracted to the mysticism - or whatever it was - of Nazism." Shirer, a fellow Iowan, later recalled that Kaltenbach was present when the French surrendered to the Nazis at Compiégne on June 22, 1940. Shirer would "never forget him [Kaltenbach] standing by my side outside the little railway carriage. ... Through the car windows you could see [Wilhelm] Keitel read the French the armistice terms. Kaltenbach, as if in a trance, gazed longingly at his Führer as other men might gaze toward their god. It was no surprise, then, when he elected to remain in Germany and betray his country." "He was," Shirer concluded, "a born Nazi."22

Kaltenbach's radio work soon became an integral part of the Nazis' worldwide propaganda campaign intended to undermine enemy morale and influence public opinion in the United States against intervention in the war. Paul Joseph Goebbels, as the Reich Minister of Propaganda, controlled the German overseas short-wave broadcasting network (Deutsche Kurzwellensender) that employed 250 people to produce and broadcast 126 hours

20. Memo, Flinn to Mumford, 3; quotes from Edwards, Berlin Calling, 8-10. See also Rolo, "Germany Calling!" 28, and idem, Radio Goes to War, 97.

21. Edwards, Berlin Calling, 12.

22. Shirer, "American Radio Traitors," 402-3. 
of propaganda daily in 14 languages. From their studios at Naven, Germany, and from ten short-wave transmitters located near Berlin at Zeesen, Nazi broadcasters were beaming twelve hours of short-wave broadcasts to the United States each day by $1939 . .^{23}$

Nazi propaganda policy was developed by Goebbels at daily staff conferences followed by smaller meetings dealing with each targeted geographic region. The heads of the U.S.A. Zone would then brief broadcasters and commentators heard by North American audiences. According to U.S. analysts, Nazi propaganda sought to split Americans from their leaders and pit labor against management, blacks against whites, and Gentiles against Jews. Clear attempts were made to enflame American isolationist passions against interventionists, all the while enhancing the image of Nazi Germany. To find broadcasters who could make their propaganda palatable to American audiences, the Nazis looked for individuals with a knowledge of the country and its culture, selecting Americans like Kaltenbach or Germans who had resided in the United States for an extended period. ${ }^{24}$

23. For the Nazi propaganda machine, see Daniel Lang, "Berlin Sends Radio Greetings," New Republic 97 (11 January 1939), 279; Harold N. Graves, Jr., "European Radio and the War," Annals of the American Academy of Political and Social Sciences 213 (January 1941), 80. See also Zeman, Nazi Propaganda, 57-59; Derrick Singleton and Arthur Weidenfeld, The Goebbels Experiment: A Study of the Nazi Propaganda Machine (New Haven, CT, 1943), 77, 81-84, 100, 143, 146, 173, 181-82, 185; Hideyo Kumata and Wilber Schramm, "The Propaganda Theory of the German Nazis," in A Psychological Warfare Casebook, ed. William E. Daugherty and Morris Janowitz (Baltimore, 1958), 53; Childs and Whitton, Propaganda by Shortwave, 19-21; Alton Frye, Nazi Germany and the American Hemisphere, 1933-1945 (New Haven, CT, 1967), 21-22; and Michael L. G. Balfour, Propaganda in War (London, 1979), 15, 24.

24. Childs and Whitton, Propaganda by Shortwave, 80-107. See also Jerome S. Bruner, "The Dimensions of Propaganda: German Short Wave Broadcasts to America," Journal of Abnormal Psychology 36 (1941), 315, 317-19, 324-27, 330; Rolo, Radio Goes to War, 644-46; Graves, "European Radio and the War," 81; Frye, Nazi Germany and the American Hemisphere, 96; "Propaganda for Blitzkrieg," in Propaganda Analysis, 4 vols. (New York, 1942), 3:105-11. For other works on Nazi propaganda, see Leonard W. Doob, "Goebbels' Principles of Propaganda," Political Science Quarterly 14 (1950), 419-42; Jay W. Baird, The Mythical World of Nazi Propaganda, 1939-1945 (Minneapolis, 1975); and Ernst Kris, German Radio Propaganda (London, 1944). 
German broadcasting, according to widely distributed programming guides, consisted of "a choice assortment of broadcasting viands, sparkling musical champagne and other tasty delicacies . . . as well as the regular news features," including four hours daily of the spoken word. Morning programs began at 6 a.m. (EST) in the United States and lasted for three hours, after which time signals from closer radio stations interfered with audio quality. The evening schedule would begin anew at 4:50 p.m. and continue until 1 a.m. In addition to broadcasts beamed directly to America, U.S. citizens could also receive Nazi transmissions to Britain beginning at 2:15 p.m. ${ }^{25}$

Programs were tailored to a wide range of tastes and all levels of culture, although the language and arguments differed according to the intended audience. For highbrow audiences Berlin produced topical talks, dramatic monologues, and question-and-answer periods; and a special series for intellectuals called "The College Hour" presented lectures such as "British Disregard for American Rights," "Paul Revere Rides Again," "Germany as I See It-By an American in Berlin," and "The U.S. and Germany - Past and Present." Yet most programs were aimed at common folk and were presented in folksy, idiomatic language, packed with wisecracks appealing to the lowest common denominator. Programming always focused on simple themes and ideas that were repeated frequently. For homemakers the Nazis produced the "Zeesen Women's Club," business people had an "Economics Review" program, GermanAmericans had German language programs, while gossips and scandal-mongers were entertained by "Charley's Cabaret" and "Mr. O.K." Anti-Semites gained perspectives on the "Jewish question" in a program called "The Jew in American History," and "for those who like Vox Pop or Amos 'n' Andy," according to one guide, "Berlin presents colloquial dialogues between 'Jim and Johnny,' 'Fritz and Fred-The Friendly Quarrelers,' and the 'Letters to Iowa.'"'26

25. Rolo, "Germany Calling!" 21, 31; Weyl, Treason, 369-70.

26. Bruner, "The Dimensions of Propaganda," 330; Childs and Whitton, Propaganda by Shortwave, 307-8; Graves, "European Radio and the War," 82; and Rolo, "Germany Calling!" 27. 
It was the "Letters to Iowa" program that introduced Kaltenbach to Americans, in particular to residents of the Midwest, who were thought to hold more isolationist views than Americans elsewhere. Kaltenbach was particularly suited to these programs, given his midwestern accent and radio style that was described as "informal, larded with American idiom." He was fond of puns, jingles, name calling, and gag lines, and often ridiculed Prime Minister Winston Churchill as "Roly-poly Windsy" and former Prime Minister Neville Chamberlain as "the Umbrella Man." The BBC was the "Bullitt-Biddle Corporation-Atrocity Manufacturers Unlimited," and listeners were encouraged to join the fictitious "British Lion Tamers' Club opened to East Indians, Irishmen, Japanese, and all others who had opposed British hegemony."27

The 1939 to 1941 "Letters to Iowa" programs consisted of purely anti-Roosevelt, anti-British, and isolationist propaganda subtly disguised as Kaltenbach's letters home read over the radio because his mail was allegedly routinely intercepted, censored, or destroyed by the British. The programs opened with "greetings to my old friend, Harry, in Iowa." One such broadcast in 1940 asked Harry, "How are all the folks and how is our old schoolmaster?" Attempting to evoke nostalgia and establish his Iowa roots, thereby making his information seem more "down home" and trustworthy, Kaltenbach once asked Harry if he remembered the pumpkin pies they used to eat together. "German housewives don't make pumpkin pies," Kaltenbach revealed, "but they get swell eating out of pumpkins in other ways." Kaltenbach would usually push propaganda in the form of advice, stating on one occasion, "Don't fall for any British propaganda, Harry. . . . It's all the bunko cooked up by that liar Winston Churchill, First Lord of the Sea Bottom." 28

\section{Edwards, Berlin Calling, 11.}

28. Quoted from "Propaganda via Short-Wave: Fred Talks to 'Dear Harry,'" in Propaganda Analysis, 3:59; and Singleton, and Weidenfeld, The Goebbels Experiment, 185-86. The "Harry" of the "Letters to lowa" program was Harry $H$. Hagemann, a Waverly, Iowa, lawyer who was a childhood acquaintance of Kaltenbach's apparently chosen at random for the broadcasts. Hagemann died in 1970. His widow and several relatives still reside in Waverly. Don L. Hagemann to author, 1 June 1993. 
Kaltenbach's broadcasts were also heard in Great Britain, where he was soon nicknamed "Lord Hee-Haw" to distinguish him from the more prominent Nazi propagandist of IrishAmerican extraction, William Joyce, who was already dubbed Lord "Haw-Haw." ${ }^{29}$ Kaltenbach welcomed the publicity and began to sign off using the new nickname. While most listeners characterized his broadcasts as light, simple, direct, unemotional, and devoid of vituperative outbursts, two radio monitors had a different assessment. "Kaltenbach's delivery and speech are marked by a certain ponderousness of approach and a heavy Teutonic brand of humor," they noted. "He is a typical representative of the atmosphere of labored facetiousness characteristic of the bulk of German transmissions for North America. Nearly every one of his broadcasts conveys this atmosphere. ${ }^{130}$

By mid-1940 Kaltenbach had become so useful to the Nazis that his radio roles were increased to include Jim, the "smartalecky Canadian," and "Honest American Fred" of the "Jim and Johnny" and "Fred and Fritz" programs. Later, Kaltenbach announced the topical talks and hosted the Saturday-evening "Military Review" program as well as a series of broadcasts titled "British Disregard for American Rights." He could be heard throughout America on Monday and Saturday evenings and Thursday and Friday afternoons. ${ }^{31}$

Kaltenbach was a part of the major Nazi propaganda effort launched in 1940 to prevent President Roosevelt's re-election to an unprecedented third term of office, an event the Nazis knew would ensure continued support for Britain. When Nazi propa-

29. The two were often confused in newspaper accounts. See, for example, Chicago Sunday Tribune, 3 December 1942; and Washington Post, morning edition, 12 September 1942, both in FBI File 65-6568-A.

30. For the critique of Kaltenbach's style, see Singleton and Weidenfeld, The Goebbels Experiment, 185. See also news article of unknown origin titled "Kaltenbach Gives Radio Talks from Berlin to Iowans," in FBI File 65-6568-5; Rolo, "Germany Calling," 28; and Edwards, Berlin Calling, 10-11.

31. "Kaltenbach Gives Radio Talks"; Edwards, Berlin Calling, 10-11. For transcripts of Kaltenbach's broadcasts, program titles, dates, and stations on which they aired, see FBI Files 65-6568-40, 45, 46, 88, 157, 182, 201. FBI File 65-6568-198 contains a complete five-page broadcast transcript from 21 July 1942; FBI File 65-6568-201 contains similar program transcripts for 30 July 1943 and 5 January 1944. 
ganda failed to bring about Roosevelt's defeat, the broadcasters shifted the emphasis to attack the efforts of the president and the interventionists to aid Britain, especially during the campaign surrounding the Lend-Lease Bill in March 1941. Concerning the Lend-Lease Act, Lord Hee-Haw remarked to Harry over the airwaves,

Now that Roosevelt has signed the Lend-Lease Bill I suppose the Germans should be bowing before the new lords of the universe, George VI and Emperor Roosevelt I. The Germans have been too busy dropping their iron pellets on Englishmen to worry about the "Union Now" boys in Washington. There is no doubt, however, that Bill 1776 cancels out the year 1776. Compared with the patriots of 1941 Benedict Arnold was a mere piker. All he did was to betray a fort to the Redcoats. The "Union Now" boys have betrayed a whole country. ${ }^{32}$

As U.S. support for Britain increased in 1941, Kaltenbach and his colleagues sought to convince Americans that Britain was lost and that any attempts to aid them would embroil Americans in a disastrous and bloody war with Germany. In the "Letters to Iowa" programs Kaltenbach urged Harry "not to bet his money on the wrong horse, because I'd sure hate to see my American friends grab the short end of the purse. ${ }^{\prime \prime 3}$

The "Letters to Iowa" programs fell far short of the goal of keeping the United States out of the war, and they failed to mold public opinion in favor of the Nazis. Yet they did bring Kaltenbach to the attention of many people in the Hawkeye state. Although it was originally thought that few Americans listened to Nazi broadcasts, it was later revealed that 150,000 to 300,000 Americans heard them. Until it was closed in June 1941, the German Library of Information in New York City mailed out 75,000 free bilingual program guides and 3,000 matrices each week, largely to the East and Midwest, as part of

32. Program quoted from Singleton and Weidenfeld, The Goebbels Experiment, 186. For dates and times of Kaltenbach's broadcasts during this period, see Edwards, Berlin Calling, 13; Memo, Flinn to Mumford, 3-4; and Waterloo Daily Courier, 7 June 1942.

33. Rolo, "Germany Calling!" 28-29; Edwards, Berlin Calling, 13. 
its "zone services." These guides contained information on shows and features, broadcast times, and gossipy articles on short-wave personalities. American newspapers and radio magazines also carried program schedules. In return, the Nazi shortwave system allegedly received 50,000 letters annually from Americans, while the NBC station in New York City, one of the nation's most powerful transmitters, received only 20,000. Kaltenbach himself received regular fan mail sent to his business address given as "Iowa. In care of the German short-wave station, Berlin." $\mathrm{He}$ in turn was a stickler for acknowledging fans in his broadcasts, and he encouraged more letters via air mail, "where British snoopers can't get at them."

KALTENBACH'S AUDIENCE, however, included far more powerful groups than British censors and Iowa farmers. The FBI had taken an interest in Kaltenbach as early as January 1940, when Iowans began to write unsolicited letters to FBI Director J. Edgar Hoover informing him of Kaltenbach's radio broadcasts and his promotion of Nazism, especially during his 1939 visit. Hoover in turn informed Assistant Secretary of State Adolf Berle that although the FBI was not actively investigating Kaltenbach's activities, it was interested in any information the State Department had. Hoover also sought the State Department's advice on how to deal with Kaltenbach if he were ever to return to the United States. Meanwhile, other federal offices were taking notice of Kaltenbach as well, including the Federal Communications Commission (FCC) and the Foreign Information Service of the Office of the Coordinator of Information (FIS/COI) under

34. Childs and Whitton, Propaganda by Shortwave, 307; Bruner, "The Dimensions of Propaganda," 335-36; Rolo, "Germany Calling!" 31; Zeman, Nazi Propaganda, 60; Graves, "European Radio and the War," 80-81; Lang, "Berlin Sends Radio Greetings," 280-81; Michael Sayers and Albert E. Kahn, Sabotage: The Secret War Against America (New York, 1944), 173; Rolo, Radio Goes to War, 98. Americans belonging to private radio monitoring groups informed the federal government that the Nazi programs could hardly help but find an audience. In 1940 Americans owned between 44 and 45 million radios, 30 percent of which had short-wave bands. Over 82 percent of American families had at least one radio that they listened to an average of 4.3 hours per day. See Paul F. Peter, "The American Listener in 1940," Annals of the American Academy of the Political and Social Sciences 213 (January 1941), 1-3. 
William J. Donovan. The FIS/COI (later the OSS and CIA) regularly tuned in to the radio traitors and in October 1941 compiled for President Roosevelt an extensive study on Americans broadcasting from Berlin. ${ }^{35}$

Even though Kaltenbach was an American citizen conducting anti-American broadcasts for a foreign government, his activities were not yet illegal. As a citizen he could accept employment by a foreign government and exercise his right to free speech over the airwaves, regardless of how odious that speech was to his fellow Americans. That changed once the United States entered the war against Germany on December 11, 1941. Yet Kaltenbach and the radio traitors continued their broadcasts, even though they had failed in their main goal of keeping the Americans out of the war and stifling aid to Britain. The new Nazi goal was to undermine America's morale and will to resist with the same tactics used against Britain. Now, however, Kaltenbach's patently pro-Nazi, anti-Allied, and anti-American broadcasts were no longer mere objectionable exercises of free speech by an American overseas; they were suddenly transformed into acts of treason committed by a citizen serving a nation with which his country was at war. After 1941, each time Kaltenbach spoke into a live radio microphone he committed an act of treason punishable by death. ${ }^{36}$

Within a week of the attack on Pearl Harbor, President Roosevelt wrote to Coordinator of Information Donovan, asking him to "talk with State and Justice [Departments] as to what should be done, now that we are at war ... in the case of American citizens who are working for enemy governments." ${ }^{\prime 37}$ Several months later, J. Edgar Hoover suggested in a memo to

35. For early FBI interest in Kaltenbach, see Memo, [name deleted] to Hoover, 30 January 1940; and Memo, Hoover to Berle, 30 January 1940, both in FBI File 65-6568-2. For COI involvement, see R\&A Report to FIS on Foreign Broadcasts from Berlin, 6 October 1941, box 8, record group 208, Records of the Office of War Information, National Archives.

36. Edwards, Berlin Calling, 10.

37. Quoted in Elliott Roosevelt and Joseph P. Lash, eds., FDR: His Personal Letters, 1928-1945, 4 vols. (New York, 1950), 2:1258, as found in box 16, Edward P. Lilly Papers, record group 218, Records of the United States Joint Chiefs of Staff, National Archives. See also box 2, ibid. 
Assistant Attorney General Wendell Berge that Kaltenbach and two other radio traitors be indicted for treason and tried as soon as they entered the United States. Hoover insisted that some immediate action be taken in 1942 to bring indictments because "if the matter is approached in a lackadaisical manner and no action taken until after their return, it is feared that postwar lethargy may prevent adequate attention being given this matter." Treasonous scoundrels such as Kaltenbach should be severely punished, Hoover believed, to prevent others from imitating their actions. "This situation," he argued, "has arisen largely as the result of totalitarian methods developed since the last war for the purpose of influencing the home front. Due to the high development and efficiency of the radio, traitors to the American way of life, who are well fitted by language and background, are obviously being exploited by the Axis powers to further their own purposes. ${ }^{\prime 38}$ Within months of Hoover's memo, Roosevelt repeated his idea to Attorney General Francis Biddle that "there are a number of Americans in Europe who are aiding Hitler ... on the radio. Why should we not proceed to indict them for treason even though we might not be able to try them until after the war?" ${ }^{\prime 39}$ Others expressed similar opinions, adding that the death penalty was more than justified for those convicted of treason. Even federal judicial officials, such as Special Prosecutor Oscar R. Ewing, who had recently obtained convictions of several pro-fascist leaders, echoed the calls for indictments and capital punishment on conviction. ${ }^{40}$

Roosevelt's memo prompted Biddle to order Hoover to launch an investigation of Kaltenbach and his fellow collaborators in late 1942. The FBI immediately dispatched agents from Washington, D.C., and seven field offices to interview Kaltenbach's former employers, classmates, siblings, neighbors, and

38. Memo, Hoover to Berge, 25 April 1942, FBI File 65-6568-30, p. 6. The others being considered for treason indictments at that time were Jane Anderson and Edward L. Delaney. Hoover suggested that propagandist Constance Drexel, who was a naturalized American, undergo denaturalization proceedings.

39. Quoted in Roosevelt, FDR: Personal Letters, 2:1348.

40. Waterloo Daily Courier, 28 August 1942; and Washington Post, 28 August 1942, both in FBI File 65-6568-1. 
acquaintances in nine Iowa cities and locations in four other states. Agents crisscrossed the nation trying to locate anyone who had ever had contact, however slight, with Lord Hee-Haw, including "Harry," the Waverly lawyer addressed in the "Letters to Iowa" programs. ${ }^{41}$

Among those questioned were Kaltenbach's brothers and sister. All of the siblings told the FBI that they were not in sympathy with what their brother was doing and that he was motivated more by money than ideology. These explanations were well known and had already appeared in the Des Moines Register when the Kaltenbachs were interviewed in late 1939. One brother thought that Frederick was perhaps "sympathetic with the Nazi cause, but that the rest of the family lives in America and believes in American principles." "We're Americans," Frederick's sister said. "We cannot be responsible for my brother's opinions." The FBI received little new information from the family, none of whom maintained contact with Frederick after 1941. None had listened to his broadcasts, even though Lord Hee-Haw was heard four times each week in their area. The subsequent FBI report stated that "the immediate family ... has an excellent reputation for loyalty to the United States." One brother, the FBI revealed, was serving with the U.S. Army, while the other brother, Rev. Gustav A. Kaltenbach, had entered the U.S. Army Chaplain Corps. ${ }^{42}$

The FBI's evidence was supplemented by articles gleaned from newspaper morgues in Waterloo, Dubuque, Des Moines, Chicago, Washington, D.C., and New York City, and by transcripts of Kaltenbach's programs that were intercepted and recorded by the FCC's Foreign Broadcast Intelligence Service

41. Agents from Washington, D.C., Philadelphia, Chicago, Denver, Milwaukee, Baltimore, Portland, and Des Moines participated and interviewed people in Waterloo, Cedar Falls, Waverly, Grinnell, Ottumwa, Des Moines, Fort Dodge, Manchester, and Dubuque, Iowa; Ironwood and Grand Rapids, Michigan; Denver, Colorado; Janesville, Wisconsin; and Portland and Eugene, Oregon. For the details of the investigation, see Summary of Facts; Memo, Flinn to Mumford, 3; "Kaltenbach - Chief of Berlin Radio Propagandists," 4; Chicago Sunday Tribune, 3 December 1942, and Washington Post, morning edition, 12 September 1942, both in FBI File 65-6568-A; Clifton, "Voice from Berlin Once an Iowan."

42. Summary of Facts; Clifton, "Voice from Berlin Once an Iowan." 
(FBIS) Monitoring Station, code-named "Shinda," at Silver Hill, Maryland, outside Washington, D.C. Every broadcast that Kaltenbach made after December 11, 1941, was recorded, and by the following October more than 126 long-playing records were available for the use of federal prosecutors. Each revealed the time, date, station frequency, call letters, and origin of the broadcast, the subject and program title, its length and language of delivery, and the identity of the announcer. ${ }^{43}$ The FBIS characterized these broadcasts as "generally critical of the Allied war leaders"; they were clearly "intended to raise doubts in the minds of American citizens over the wisdom of participating in the war at all." Witnesses were available, the FBIS added, "who have heard the broadcasts and/or can recognize the Subject [Kaltenbach], and/or can identify that they have seen the Subject in Germany." In order to get an exact recording of Kaltenbach's voice that could be scientifically confirmed as his, the FBI made anonymous appeals via fan mail that Kaltenbach spell out, letter-by-letter, the names of American POWs during one of his broadcasts rather than just recite their names. Kaltenbach, not suspecting the true reason for this request, fully complied, slowly and clearly enunciating the letters in the names of several POWs during an April 1943 program. This recording was added to the growing body of evidence against him.4.

On January 13 the Justice Department confirmed abundant rumors that the FBI was investigating those accused of being Nazi propagandists. The FBI had sought to compile an overwhelming mass of material to ensure treason indictments; the FBI file on Kaltenbach alone eventually exceeded five hundred pages. ${ }^{45}$ The evidence was presented to a federal grand jury in Washington, D.C., in the spring of 1943, and indictments were

43. More than 800 boxes of FBIS transcripts, digests, and recordings of monitored foreign broadcasts from 1940-1946 are available in record group 262, Records of the Foreign Broadcast Intelligence Service, National Archives.

44. Summary of Facts. For lists of Kaltenbach's broadcasts, see FBI Files 65$6568-40,45,46,88,157$, and 182 . The details of the program Kaltenbach was requested to make are described in FBI Files 65-6568-105 and 106.

45. J. Kevin O'Brien, Chief FOIA Section, FBI, Washington, D.C., to author, 21 January 1992. 
were returned against Kaltenbach and eight others on July $26{ }^{46}$ No warrant was issued for Kaltenbach's arrest since he was still in Germany, but Hoover intended to have a warrant ready and waiting the second he set foot on U.S. soil. ${ }^{47}$

Hoover sent information on Kaltenbach and the other indicted traitors to the U.S. Office of War Information, to Criminal Investigation Corps (CIC) officers in the 12th Army Group, and to officers of the Psychological Warfare Division (PWD/SHAEF) in Europe so they could apprehend Kaltenbach when Germany fell. PWD/SHAEF had already compiled their own list of 46 American and 45 British renegades suspected of collaborating with the Nazis; that list eventually grew to include 141 Americans. PWD issued detailed instructions for the treatment of these renegades once they were captured, and encouraged its personnel to scour all captured radio facilities in occupied Europe and Germany for evidence in the form of recordings, correspondence, pay vouchers, and employment records that could aid in convicting each suspect. ${ }^{48}$

Kaltenbach was stunned when he heard the BBC announcement of his indictment. He broadcast a reply on July 30,1943, sounding, to William Shirer, "as though he were hurt." "Technically I suppose I am guilty of treason," he conceded, "of treason to Roosevelt and his warmongers, but not to the American people." Kaltenbach declared that he served the Reich "out of

46. The other radio traitors indicted were Jane Anderson (from Atlanta), Robert Best (Sumter, SC), Douglas Chandler (Baltimore), Edward L. Delaney (Olney, IL), Constance Drexel (Philadelphia), and Max Otto Koischwitz and Ezra Pound (New York City). Mildred Gillars ("Axis Sally") from Columbus, Ohio, although later prosecuted and imprisoned, was not among those indicted in 1943.

47. Washington Daily News, 13 January 1943, in FBI File 65-6568-78; the indictment is contained in Summary of Facts.

48. Memo, SHAEF to All Concerned, 10 December 1944, and Memo, SHAEF to Circulation, 2 April 1945, both in box 26, record group 331, Records of Allied Operational and Occupational Headquarters, World War II, Records of the Psychological Warfare Division, SHAEF, 1942-1945, National Archives. See also Memo, Head Special Warfare Branch, ONI, OP-16-W, U.S. Navy to Overseas Branch, OWI, 20 November 1943, box 109, record group 208, National Archives; Memo, [name deleted], to Director, FBI, 21 October 1944, FBI File 65-6568-182; and Memo, J. A. Cimperman, Assistant Legal Attaché, U.S. Embassy, London, to Director, FBI, 4 September 1944, FBI File 65-6568-178. 
a genuine desire to promote good relations between Germany, the land of my father, and America the land of my birth."

To have deserted the German people would have been an act of treason against my conscience. Thus on December 8, 1941, I was suddenly confronted with the choice of committing a possible act of treason against my native America, or of deserting the German people in their hour of need. If I had taken the easy way out, I could have ceased my broadcasting activities with the excuse that as an American I should not be expected any longer to plead the cause of a country with which America was at war. . . It was not easy to turn my back perhaps forever on my friends in the United States, never to see the land of my birth again. I made then my choice, and I have never regretted that choice for an instant. Not even now.

In closing, Kaltenbach refused to make "apologies for doing my allotted bit to help the German people to a better future." "I am not an enemy of the American people," he reiterated, "but I shall remain an impossible enemy of those forces in America who wish to deny Germany her rightful place in the European sun." He closed by using Patrick Henry's words: "If that be treason, make the most of it. ${ }^{\prime 49}$

IN THE MONTHS following Kaltenbach's indictment, as the Nazis recognized that Kaltenbach's propaganda, and that of the other radio traitors, had no discernable effect on the Allied war effort, the frequency of his radio broadcasts diminished. A few of the American broadcasters were pulled from the air as complete failures or for being counterproductive, but Kaltenbach could still be heard in North America and by GIs in the field between 1943 and early $1945 .^{50}$ His tired Nazi propaganda slo-

49. Shirer, "American Radio Traitors," 404. See also Case Report, Frederick Wilhelm Kaltenbach, 18 April 1945, FBI File 65-6568-171. For a transcript of Kaltenbach's 30 July 1943 broadcast, see FBI File 65-6568-201.

50. Propagandist Jane Anderson was pulled from the air in 1943 as being completely ineffective. See Conyers-Read COI/OSS History, pp. 50-51, box 72, record group 226, Records of the Office of Strategic Services, National Archives. 
gans and themes, however, were out of touch with reality and were received with laughter, derision, and only passing curiosity. As Germany neared defeat, Kaltenbach's shrill denunciations of Allied leaders and his patently false claims of Nazi victories were ludicrous to even the lowest-ranking GIs, who saw evidence to the contrary every day. The only groups who still paid close attention to Kaltenbach were those few radio monitors and FBI agents seeking further evidence to use against him.

Kaltenbach's health declined precipitously during the last eighteen months of the war as he began to suffer from heart problems and asthma. He also grew critical of Hitler and the Nazis, often refusing to broadcast and going on strike, sometimes for months at a time. His attitudes and opinions alienated his fellow collaborators and resulted in confrontations with many, most notably with Lord Haw-Haw, who did not share Kaltenbach's pessimism. According to Dorothea Kaltenbach, the disputes between Lord Hee-Haw and Lord Haw-Haw became so acrimonious that she feared William Joyce "would liked to have killed my husband." Frau Kaltenbach later told U.S. Army officials that her husband's work for the Nazis never produced any riches or rewards, and that, like most collaborators, they were considered outsiders of doubtful loyalty and were always held at arm's length. Kaltenbach was never a Nazi, his wife later claimed, and he supposedly "hated Hitler," making "broadcasts only in the hope of keeping the U.S. out of the war." As the Allies closed in, Kaltenbach, like many Nazis, attempted to curry favor with anti-Nazi elements and "actively befriended the ... religious elements associated with Reverend [Martin] Niemoller," all to no avail. ${ }^{51}$

Little is known of Kaltenbach's activities during the final months of the war or during the fall of Berlin in April 1945. On May 15, 1945, however, just as U.S. Army CIC officers were going to Kaltenbach's Berlin residence to place him under arrest, he was taken into custody by Soviet agents who had accompanied Russian troops into the city. Kaltenbach had attempted to

51. Quotes from Washington Post, 10 July 1945. See also Washington Star, 12 July 1945; Stars and Stripes, London edition, 10 September 1945; and Washington Times-Herald, 21 July 1946. 
use his American citizenship to avoid arrest by hanging a large sign bearing the word Americansky on his apartment door. ${ }^{52}$

Kaltenbach's fate was soon caught up in the growing tensions between the U.S. and the U.S.S.R. Acting on information provided by his wife, U.S. Army officials attempted to contact Soviet authorities to seek his apprehension. But months went by before official contact was made with the Soviets. Then the Soviets denied they held Kaltenbach. The army and FBI were certain, however, that Kaltenbach was in Soviet custody. In August 1945 the Americans learned that Kaltenbach was in a detention camp at Frankfurt-on-Oder, but attempts by the U.S. Army to arrange a trade for two SS officers failed because the Soviets denied they held Kaltenbach. By early September 1945, army investigators traced Kaltenbach to two other camps without catching up with him. In early October 1945 Soviet officials informed the army yet again that "they do not have Kaltenbach in custody, which means that the matter is officially closed."

In March 1946, however, the army received word from repatriated POWs that Lord Hee-Haw was in Soviet custody near Weimar. Because the Soviets still insisted that they did not have him, both army officials and Kaltenbach's wife, now living in the American Zone of Berlin and working for the U.S. Army as a translator, doubted he would ever be found. His wife, who had heard from Kaltenbach only once since his arrest, feared that his ill health would result in his death in captivity. Although the Americans again requested Kaltenbach's release, Soviet agents ignored them, causing one officer to report that the army had "practically given up hope." ${ }^{15}$

A break in the case occurred in June 1946, when the Soviets suddenly admitted having Kaltenbach and promised to release him within a week to ten days. Yet when the deadline had ex-

52. Washington Post, 10 July 1945 . See also Daily Worker, 10 July 1945 . The date of Kaltenbach's arrest was later inexplicably changed in newspaper reports to 14 June and then to 14 July 1945.

53. Letter, [name deleted] to Director, FBI, 10 August 1945, FBI File 65-6568211; Washington Times-Herald, 21 July 1946. See also Stars and Stripes, London edition, 10 September 1945; Letter, [name deleted] to Hoover, 11 October 1945. FBI File 65-6568-217; and Edwards, Berlin Calling, 15.

54. Stars and Stripes, 10 March and 17 May 1946. 
pired, a Red Army major general notified U.S. Army headquarters in Germany that after a long investigation it was discovered that Frederick W. Kaltenbach had died of natural causes in October 1945 somewhere in the Soviet Zone. Army officials insisted on seeing camp records and a death certificate to confirm both the time and cause of death, but the Soviets responded that no such records existed and that the location of Kaltenbach's remains were unknown. Frau Kaltenbach refused to believe the Soviets until she saw the body herself or heard a report of her husband's death from someone she knew. The U.S. Army continued to request records, but nothing more came from behind the Iron Curtain. ${ }^{55}$

Back in the United States, the Justice Department still had an outstanding indictment and was hesitant to accept Soviet reports of Kaltenbach's death. Instead, in September 1946, the department notified intelligence officials in France and Germany to remain on the lookout for Kaltenbach among repatriated POWs returning from the Soviet Zone. During the following two years, however, no sign of Kaltenbach emerged. Finally, army officials concluded that Kaltenbach had indeed died in Soviet captivity and that "more definite" details would probably never be available. When the State Department agreed with the army's assessment and suggested that Kaltenbach's case be closed, the FBI complied, and the U.S. District Court dismissed the indictment against Kaltenbach on April 13, 1948. ${ }^{56}$

AS A NAZI PROPAGANDIST, Frederick Kaltenbach was an abject failure. His work for the Nazis did little to dissuade Americans from supporting the war effort, and he accomplished little unique during his life other than earning himself a place among the small numbers of Americans who betrayed their

55. Washington Post, 21 July 1946. See also Washington Star, 21 July 1946.

56. Quote from Telegram, Horton R. Telford, Legal Attaché, U.S. State Department, Paris, to Director FBI, 29 December 1947, FBI File 65-6568-237. See also Telegram, FBI to Attaché, Paris, 12 September 1946, FBI File 65-6568-226; Memo, [name deleted] to Director, FBI, 27 September 1947, FBI File 65-6568232; Memo, [name deleted] to Director, FBI, 3 November 1948, FBI File 656568-241; and Memo, [name deleted] to Director, FBI, 28 June 1950, FBI Files 65-6568-243. 
country during wartime. Unlike Benedict Arnold or even his contemporary, the poet-turned-propagandist Ezra Pound, however, Kaltenbach is largely forgotten by history.

Perhaps the most significant aspect of Kaltenbach's story is that it reveals how one seemingly rational and intelligent American grasped fascism as the answer to the real and perceived ills of western civilization during the interwar years. In this, his reaction to the turmoil of the times was not unlike that of many other Americans and Europeans, people who in most respects were typical citizens of normal means, circumstances, and backgrounds. Kaltenbach sincerely believed in the false promises of Nazism and felt that his work was a true sign of German and American patriotism. While millions shared Kaltenbach's beliefs and philosophies, only a few chose to take those beliefs to the extreme of committing treason in the attempt to make a new world according to the designs of Adolf Hitler and National Socialism. 
Copyright of Annals of Iowa is the property of State of Iowa, by \& through the State Historical Society of Iowa and its content may not be copied or emailed to multiple sites or posted to a listserv without the copyright holder's express written permission. However, users may print, download, or email articles for individual use. 